\title{
ASSESSMENT OF TRANSPORTATION IMPACT ON REGIONAL DEVELOPMENT: CASE STUDY OF UKRAINE
}

(D) Natalia Masliii ${ }^{1}$, Doctor of Economic Sciences / Associate Professor;

(D) Valerijs Skribans², Dr.oec./ Research Professor

\author{
${ }^{1}$ Odessa I.I. Mechnikov National University, Ukraine; ${ }^{1}$ Institute of Market Problems and \\ Economic-Ecological Research of the Academy of Sciences of Ukraine, Ukraine; \\ ${ }^{3}$ Riga Technical University, Latvia
}

\begin{abstract}
An important consequence of development of transport complex of country is a growth of economic and social well-being of population. Focus on optimally functioning transport should be considered as an important factor in sustainable economic development, and deviations from optimal values as an indicator of additional reserves for growth. Defining national economic interests is one of the main tasks of Ukraine's development. In order to develop independently, and at the same time on the basis of partnership and cooperation, it is necessary to develop transport provision for the regions and interregional integration to form a whole transport space. The author's approach in considering this problem using general scientific and special methods of scientific research made it possible to investigate these processes. The article describes a methodological approach to the study of the transportation in the regions of Ukraine on the basis of intermodality and multimodality using forms of scientific - technical and static analysis, which will contribute to the implementation of the state policy of interregional integration, taking into account freight transportation using various types of transport. A scientific and applied approach has been proposed for determining the interdependence of the gross regional product per person on the freight turnover by kind of transport by using the methodological tools of the system analysis theory in order to identify transport regions and efficiently locate multimodal terminals (transport hubs), which will contribute to the implementation of effective instruments to promote interregional integration and regional economic integration, information, education spaces into a single transport space, overcoming interregional alienation and the introduction of effective instruments of state support for interregional integration, will contribute to the implementation of interregional programs and projects.
\end{abstract}

Key words: transport; region; interregional development; transport space; intermodal and multimodal transportation; gross regional product per capita; freight turnover; transport provision.

JEL code: R11, R41, R58

\section{Introduction}

Transport plays an important role in the functioning and development of the region's economy, providing inter-regional communication based on production and consumption, meeting the needs of the population and enterprises. The modern transport system of Ukraine and its regions is going through a period of deep systemic crisis, since the state of the infrastructure and the level of organization of transportation in many prospects do not meet the growing needs of society and European quality standards for the provision of transport services. This reduces the efficiency of the functioning of the transport system of the regions and necessitates its development by creating various committees, networks, platforms, directives, regional development strategies that guarantee continuous cooperation at all levels.

The aim of the research is to develop a model for the evaluation of relationship between gross regional product (GRP) per capita and freight turnover by regions of Ukraine for estimation of transportation impact on regional development.

Research tasks are:

1) to study international literature in the field;

2) to choose an appropriate method for model development;

3) to study indicators of freight turnover and GRP per capita by regions of Ukraine; 
4) to develop a system of equations (model) for the evaluation of relationship between GRP per capita and freight turnover by regions of Ukraine;

5) to estimate model application for regions of Ukraine: to develop a comparative analysis of transport support, freight turnover and GRP per capita;

6) to substantiate the construction of centres for interregional transport integration in the regions of Ukraine.

Study of the compliance of the transport infrastructure of the regions of Ukraine are limited by the following criteria: time limit - last 5 years; geography - territory of Ukraine; statistical - quantitative and qualitative indicators of regional development; economic - GRP per capita shows the well-being of residents of a particular territory; freight turnover of regions; infrastructural - transport support.

Novelty the research is: a scientific and applied approach is proposed for assessing the provision of interregional development of the transport space of Ukraine, the basis of which is the identification of the interdependence of the GRP per person on the freight turnover by mode of transport by using the methodological tools of the theory of system analysis and economic and statistical analysis in order to form an effective state policy for the development of the transport sector in the economic regions of Ukraine on the basis of intermodality and multimodality.

\section{Materials and Methods}

The research materials and methods choose is based on international literature analysis.

Scientists from all over the world are constantly researching the transport provision of regions of different countries. In particular, American scientists (Soyres, et al., 2020) present a structural general equilibrium model to analyse the effects on trade, welfare, and gross domestic product of common transport infrastructure; scientists in Norway (Hansen \& Johansen, 2017) have analysed the wider economic impacts (WEI) of a large number of planned Norwegian transport infrastructure projects; the example of Belgium (Meersman \& Nazemzadeh, 2017) calls to considering the contribution of transport infrastructure to economic activity; in Chinese regions (Yu, et al., 2013) scientists examine the possibility of spatial spillover effects of transport infrastructure; scientists also have analysed the place and role of transport infrastructure in the interregional integration of the Russian Federation regions (Gadelshina \& Vakhitova, 2015); the example of Spain (Mohíno, et al., 2016) has proposed an approach to multimodal and diachronic accessibility of the transport network, which made it possible to evaluate the usefulness of accessibility for assessing regional interconnections, interactions and competition. On the example of Nepal (Pokharel, et al., 2021), two independent effects were identified in qualification of overall patterns - the impact of market potential on city primacy and the impact of highly localized, immobile resources on GDP.

The issues of transport support for the regions of Ukraine are reflected in the works on the analysis of the dynamics of the main indicators of the development of the transport and logistics system of the regions (Ivanov, et al. 2019; Chernyshev, et al., 2019), which applied econometric modelling to study the interdependence of GRP on the volume of imports and exports. An assessment of the level of provision of transport infrastructure in the border regions of Ukraine was also carried out and directions for the further development of the industry were determined (Hudyma, 2013); an assessment of the development and location of the transport and road complex of Ukraine was carried out (Pashchenko, 2003); methodological approaches to assessing the effectiveness of the participation of railway transport in the logistics systems of the region are presented (Stetsyuk \& Kostyaeva, 2017); the systematization of directions of state support for the development of the transport industry as a basic branch of the economy is considered (Khrustalyova, 2013). However, in the context of dynamic changes taking place in the world and affecting 
the country's economy, constant monitoring requires changes in the indicators of freight turnover, exports, imports and their impact on GRP.

Among the scientific achievements in the development of freight and passenger transportation by various types of transport and their integration, it should be noted: analysis of the current state of development of multimodal transport of goods and research into the feasibility of forming transport and logistics centers and transport and logistics clusters to intensify the development of multimodal transport of goods in Ukraine (Karpenko \& Babyna, 2013); principles of logistics in multimodal transportation of goods (Shyriaieva, 2012); patterns and features of the development of the transport and logistics system in the existing legal field and developed proposals for improving the transit policy of Ukraine in modern conditions (Braginskiy, 2011).

Among the methods for model development are systems of linear equations, systems of nonlinear equations, interpolation and extrapolation; including matrix method, iteration method, bisection method, horde method (proportional division method), Newton method (tangent method) and so on. For the research authors selected method of systems of linear equations, which in common form is shown below:

$$
\begin{gathered}
a_{11} x_{1}+a_{12} x_{2}+\cdots+a_{1 j} x_{j}+a_{1 n} x_{n}=b_{1} \\
a_{21} x_{1}+a_{22} x_{2}+\cdots+a_{2 j} x_{j}+a_{2 n} x_{n}=b_{2} \\
\cdots \\
a_{i 1} x_{1}+a_{\mathrm{i} 2} x_{2}+\cdots+a_{\mathrm{i} j} x_{j}+a_{\mathrm{i} n} x_{n}=b_{\mathrm{i}} \\
\cdots \\
a_{m 1} x_{1}+a_{\mathrm{m} 2} x_{2}+\cdots+a_{\mathrm{m} j} x_{j}+a_{\mathrm{m} n} x_{n}=b_{\mathrm{m}}
\end{gathered}
$$

In the research we combine one factor linear regression equations, logarithmic regression equations, moving average, polynomial equations, including polynomial equations of the $2^{\text {nd }}, 3^{\text {rd }}$ and $4^{\text {th }}$ degree. The selection of equations type was related to the quality of equations ( $R^{2}$, Durbin-Watson and t-statistic).

\section{Research results}

According to the State Statistics Service of Ukraine (State Statistics Service of Ukraine, n.d.), the total transport network of Ukraine covers $166.1 \mathrm{th}$. $\mathrm{km}$ of hard-surface roads; 21.6 thousand km of railways, ranking second place in Europe: 2.1 thou km of operational river shipping routes with access to the Azov and Black Seas, along which there are 10 river ports; 18 seaports in the Black Sea, Azov and Danube basins 33 airports, 17 of which are international: 4.4. thou $\mathrm{km}$ of trolleybus lines; 1.9 thou km of tram lines; 0.1 . th. $\mathrm{km}$ of metro tracks; 4.8 thou km of main oil pipelines; 3.9 thou $\mathrm{km}$ of gas pipelines and 1.0 thou $\mathrm{km}$ of ammonia pipelines. It is advisable to analyse the transport provision of the regions of Ukraine in the context of nine economic regions (Zastavny, 2010). Such an analysis will allow planning activities for interregional cooperation based on the exchange of experience and the development of a regional policy of Ukraine in the transport sector.

Previous studies based on the economic models have shown that the GRP per person from the main indicators of the development of the country's economic regions, in particular, the balance of exports and imports of goods and services of the region, average monthly wages, the volume of educational and medical subventions, are influenced by all the studied indicators (Demianchuk, et al., 2019 a; Demianchuk, et al., 2021). It has been proved that in order to solve the identified problems, it is necessary to form sustainable development of the country's economic regions, which should contribute to solving the problems of ensuring equal opportunities for economic activity for the population, business and stimulating a competitive economy, reducing disparities and developing small towns, cities, regions and economic regions of the 
country (Demianchuk, et al., 2019 b). One of these issues is the development of transport support for the economic regions of Ukraine (Maslii, 2020; Maslii, et al., 2020; Ilchenko, et al., 2019).

Indicators of freight turnover and GRP volumes per person by region are presented in table 1.

Table 1

GRP per person and freight turnover by regions in Ukraine

\begin{tabular}{|c|c|c|c|c|c|c|c|c|c|c|}
\hline \multirow{2}{*}{ Regions } & \multicolumn{5}{|c|}{ Gross regional product per person, UAH } & \multicolumn{5}{|c|}{ Freight turnover, mln. tkm } \\
\hline & 2015 & 2016 & 2017 & 2018 & 2019 & 2015 & 2016 & 2017 & 2018 & 2019 \\
\hline Kiev & 46058 & 60109 & 74216 & 90027 & 112521 & 2658 & 1736 & 1744 & 8836 & 10001 \\
\hline Zhytomyr & 23678 & 30698 & 38520 & 49737 & 62911 & 3852 & 3275 & 4044 & 4326 & 4455 \\
\hline Chernihiv & 26530 & 35196 & 41726 & 55198 & 69725 & 466 & 727 & 886 & 988 & 1075 \\
\hline Kharkiv & 35328 & 45816 & 57150 & 69489 & 86904 & 23775 & 24013 & 23944 & 21297 & 19055 \\
\hline Sumy & 26943 & 37170 & 41741 & 51419 & 62955 & 8793 & 6867 & 7371 & 6855 & 7944 \\
\hline Poltava & 48040 & 66390 & 81145 & 106248 & 123763 & 7433 & 6961 & 6993 & 6677 & 7433 \\
\hline Donetsk & 27771 & 26864 & 32318 & 39411 & 45959 & 702 & 597 & 438 & 13637 & 12395 \\
\hline Luhansk & 14079 & 10778 & 14251 & 13883 & 16301 & 212 & 273 & 463 & 384 & 548 \\
\hline Dnipropetrovsk & 53749 & 65897 & 75396 & 97137 & 114784 & 22744 & 27065 & 26475 & 27056 & 25451 \\
\hline Zaporizhzhia & 37251 & 50609 & 59729 & 75306 & 85784 & 7928 & 8720 & 9441 & 9933 & 9983 \\
\hline Cherkasy & 30628 & 40759 & 48025 & 59697 & 76904 & 10041 & 9850 & 10562 & 9919 & 10764 \\
\hline Kirovograd & 29223 & 39356 & 47469 & 55183 & 67763 & 29632 & 25161 & 26447 & 26128 & 26945 \\
\hline Vinnytsia & 27249 & 37270 & 46615 & 58384 & 71104 & 26044 & 25133 & 27271 & 27154 & 24511 \\
\hline Ternopil & 20228 & 24963 & 29247 & 38593 & 46833 & 2054 & 2020 & 2108 & 2646 & 1817 \\
\hline Khmelnitsky & 24662 & 31660 & 37881 & 49916 & 59583 & 1809 & 1727 & 1630 & 1541 & 1596 \\
\hline Transcarpathia & 19170 & 22989 & 25727 & 34202 & 41706 & 7227 & 7342 & 7886 & 7572 & 7307 \\
\hline Lviv & 28731 & 37338 & 45319 & 58221 & 70173 & 10391 & 10516 & 10973 & 11352 & 10479 \\
\hline Ivano-Frankivsk & 27232 & 33170 & 37220 & 46312 & 57033 & 1258 & 1352 & 1178 & 1140 & 1236 \\
\hline Chernivtsi & 16552 & 20338 & 23365 & 31509 & 37441 & 956 & 1018 & 1106 & 1258 & 1457 \\
\hline Volyn & 23218 & 30387 & 34310 & 49987 & 58297 & 1380 & 1436 & 1606 & 1847 & 1984 \\
\hline Rovny & 24762 & 30350 & 33958 & 42038 & 49044 & 9699 & 10311 & 10990 & 10307 & 11057 \\
\hline Nikolaev & 30357 & 41501 & 50091 & 60549 & 70336 & 786 & 841 & 874 & 1110 & 1195 \\
\hline Odessa & 31268 & 41682 & 50159 & 62701 & 72738 & 69470 & 61759 & 65274 & 63195 & 65950 \\
\hline Kherson & 21725 & 30246 & 36585 & 45532 & 52922 & 5158 & 5225 & 5373 & 5097 & 1271 \\
\hline
\end{tabular}

\section{Source: constructed by the authors based on data from http://www.ukrstat.gov.ua}

In order to determine the impact of the development of the transport sector on the state of socioeconomic development of regions and justify the need to develop a state policy of integration in the direction of the development of transport provision for the regions of Ukraine on the basis of intermodality and multimodality, we will analyse the interdependence of freight turnover and the volume of its gross regional product per person using this forms of technical analysis as a trend line. It is a straight or curved line that approximates the initial data based on a regression equation or a moving average. The approximation is determined using the least squares method. Depending on the nature of the behavior of the initial data (decrease, increase, etc.), an interpolation method is selected that should be used to build a trend. 
Constructed system of equations by regions in Ukraine are shown below:

Kiev
Zhytomyr
Chernihiv
Kharkiv
Sumy
Poltava
Donetsk
Luhansk
Dnipropetrovsk
Zaporizhzhia
Cherkasy
Kirovograd
Vinnytsia
Ternopil
Khmelnitsky
Transcarpathia
Lviv
Ivano-Frankivsk
Chernivtsi
Volyn
Rovny
Nikolaev
Odessa
Kherson

Kherson

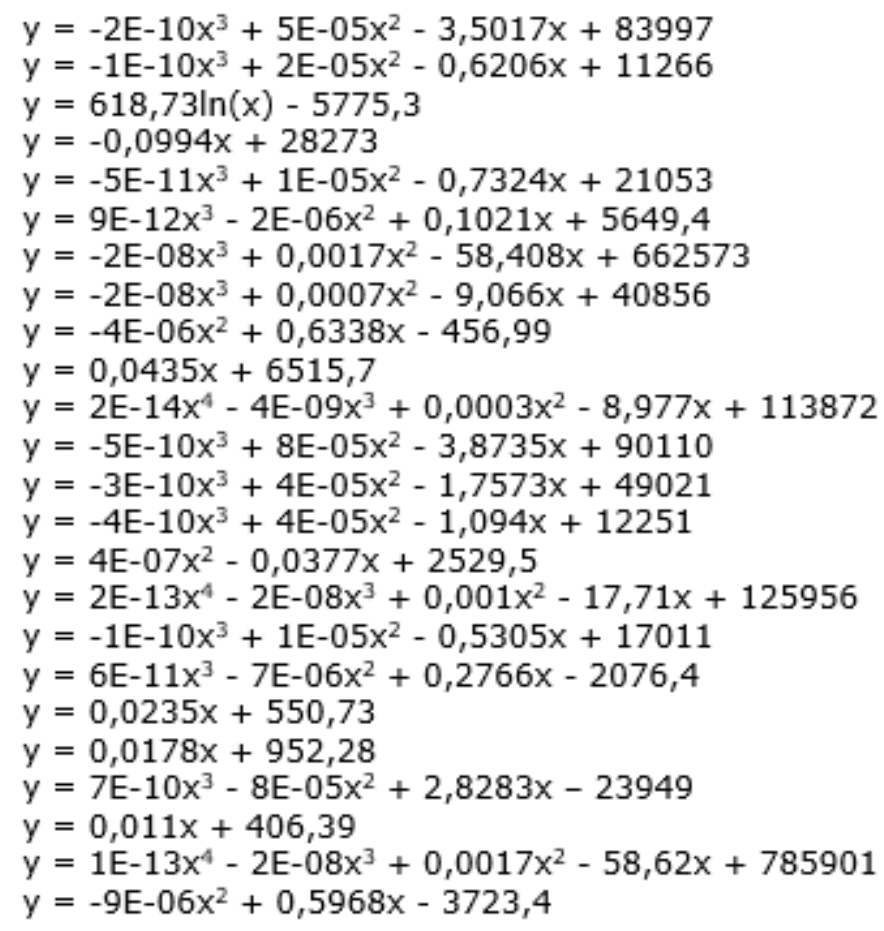

Where:

$$
\begin{aligned}
& y \text { - freight turnover; } \\
& x \text { - GRP per capita. }
\end{aligned}
$$

\section{Model estimation and discussion}

Freight turnover and volume of GRP per person in the Kiev and Zhytomyr regions are in a polynomial dependence of the $3^{\text {rd }}$ degree, which indicates an interconnected alternating increase and decrease in the values of indicators, i.e. unstable influence; in the Chernihiv region - in a logarithmic relationship, that is, the indicated values had a rapid interrelated growth with subsequent gradual stabilization. Due to the significant transit potential and the developed transport infrastructure of the Kiev region, an increase in exports to European markets is possible.

Taking into account the favorable transport and geographical position of the Zhytomyr region (transport corridors, proximity to the capital of Ukraine), it is promising to use the transit movement of goods and services, cooperation with neighbouring regions etc., and the presence of an external border with the Belarus provides an opportunity for cross-border cooperation The development of the transport industry in the Chernihiv region will be facilitated by the existing transit potential of the Baltic-Black Sea route (international checkpoints, transport corridors and European highways, existing waterways).

Freight turnover and volume of GRP per person in the Kharkiv region have a linear approximation, which indicates a direct influence and interdependence, which is characterized by growth at a constant rate; in the Sumy and Poltava regions is in a polynomial dependence of the $3^{\text {rd }}$ degree, which indicates an interconnected alternating increase and decrease in the values of indicators, i.e. unstable influence.

Despite the fact that the Kharkiv region is a logistics center with a developed transport infrastructure, including an international airport, which contributes to the development of cooperation within the framework of the Association Agreement with the EU, with the political support of the EU and other countries of the world, it makes it necessary to create new poles of economic growth in the region as a powerful regional center of international transport and economic relations of the country. For the Sumy 
region, an important development element is to ensure the proper condition of the road transport infrastructure and transport links of the territories by ensuring transport accessibility. Proceeding from the fact that the Poltava region is located in the center of the country and given the presence of a developed transport network and satisfies only the basic needs of the population and the economy in transportation in terms of volume (and not quality), and its current state does not fully meet the requirements of the effective implementation of the European integration course Ukraine and the integration of the national transport network into the Trans-European transport network, it is necessary to increase the efficiency and competitiveness of the transport industry, strengthen interaction between the public and private sectors, public authorities and local governments, contribute to the creation of all the necessary prerequisites for the creation of an international transport corridor on its territory. A developed transport infrastructure, a system of logistics and forwarding services are of strategic importance for the country's economic growth.

Freight turnover and volume of GRP per person in Donetsk and Lugansk regions are in a polynomial dependence of the $3^{\text {rd }}$ degree, which indicates an interconnected alternating increase and decrease in the values of indicators, i.e. unstable influence. Despite the consequences of the armed conflict on the territory of the economic region, transport and logistics links both inside and with other regions and countries are hampered.

At the same time, all types of transport communications, including road, rail, sea and air transport, experience negative consequences. In the territory controlled by the Ukrainian authorities, the potential for the restoration and development of communications is preserved, taking into account the reorientation of transport links, which can be realized through the development of the existing and construction of new infrastructure for road, rail and sea transport, the development and technical modernization of the port infrastructure of the "Mariupol Sea Commercial Port" to restore its capacity; restoration of transport passenger and cargo air traffic; creation of transport and logistics clusters and basic logistics centers, taking into account the reorientation of traffic flows; introduction of innovative technologies and information systems for the management of the transport system based on electronic management. Thus, an important condition for the development of the transport sector is the restoration and gradual development of the regional infrastructure, primarily the logistics and transport network and the energy network.

Freight turnover and volume of GRP per person in the Dnipropetrovsk region is in a polynomial dependence of the $2^{\text {nd }}$ degree, which indicates an interconnected alternating increase and decrease in the values of indicators, i.e. unstable influence; in the Zaporozhye region trend have a linear approximation, which indicates a direct influence and interdependence, which is characterized by growth at a constant rate. Modernization of transport and logistics infrastructure is important for the effective functioning of the economy, namely, it acts as an important factor in the formation of aggregate demand (logistics systems are associated with obtaining 20-30 \% of the gross national product of industrialized countries), increasing the turnover of wholesale and retail trade, increasing the investment attractiveness of territories, and also carries positive effects, which are to reduce the influence of the distance between regions, ensure the integration of the national market and reduce the cost of transportation to the markets of other countries and regions.

Freight turnover and volume of GRP per person in the Cherkassy and Kirovograd regions is in a polynomial relationship of 4 degrees and 3 degrees, respectively, which indicates an interconnected alternating increase and decrease in the values of indicators, i.e. unstable influence.

The location of the economic region in the geographical center of Ukraine, at the intersection of international air corridors, the presence of important highways passing through the territory of the region, large railway junctions, as well as the main waterway of the country, the Dnieper River, opens up 
opportunities for the development of transport infrastructure. Attraction of grant funds for the implementation of regional development projects will contribute to bringing the vast majority of road transport infrastructure facilities into proper technical condition based on intermodality and multimodality.

Freight turnover and volume of GRP per person in the Vinnitsa and Ternopil regions is in a polynomial relationship of 3 degrees, in the Khmelnytsky region - 2 degrees, which indicates an interconnected alternating increase and decrease in the values of indicators, i.e. unstable influence. Taking into account the unsatisfactory condition of highways, the transit provision of the region is not fully implemented and given the constant progressing process of the growth of the car park, in a few years the number of vehicles, the risks of accidents and losses from them will significantly increase. If fundamental measures are not taken to improve road safety, the process of attracting investments into the regional economy will be held back due to the danger of movement and transportation. The rapid destruction of road structures is caused by an increase in weight loads from vehicles, traffic intensity for which the existing road network is not designed.

Therefore, in order to develop the transport subsystem, it is advisable to update and expand the number of rolling stock units of all components of the transport subsystem, especially the railway one.

Freight turnover and volume of GRP per person in the Transcarpathian region is in a polynomial dependence of the $4^{\text {th }}$ degree, in the Ivano-Frankivsk and Lviv regions -2 degrees, which indicates an interconnected alternating increase and decrease in the values of indicators, i.e. unstable influence; in the Chernivtsi region - a linear approximation, which indicates a direct influence and interdependence, which is characterized by growth at a constant rate. A significant renewal of all types of infrastructure in Transcarpathia, transport and road, communal and border, environmental, energy, industry and communications, social, tourism based on EU standards and regulations will accelerate the achievement of competitiveness and innovativeness of the regional economy of the Transcarpathian region.

Taking into account the fact that the Ivano-Frankivsk region has a fairly powerful transport complex that provides transit, interregional and intraregional transport links, the priority tasks for its development are to ensure transport accessibility, modernization of the Ivano-Frankivsk International Airport, which, in turn, will lead to an increase in investment attractiveness and development of production, and the successful location and availability of international transport corridors, important main railways plays a leading role in increasing freight traffic and developing a transport (logistics) hub in the region.

Freight turnover and volume of GRP per person in the Volyn region have a linear approximation, which indicates a direct influence and interdependence, which is characterized by growth at a constant rate; in the Rivne region - in a polynomial dependence of the $3^{\text {rd }}$ degree, which indicates an interconnected alternating increase and decrease in the values of indicators, i.e. unstable influence. The network of highways and railways available in the Volyn region is, in general, sufficient to ensure the development of the volumes of freight and passenger traffic expected in the medium term. At the same time, the existing infrastructure needs significant modernization in order to bring it closer to the standards of the European Union. The network of highways and railways available in the Rivne region is generally sufficient to ensure the development of the expected medium-term volumes of freight and passenger traffic.

At the same time, the corresponding infrastructure needs significant modernization in order to bring it closer to the standards of the EU. The infrastructure of checkpoints needs to be improved and developed in order to increase their throughput. The development of "Rivne International Airport" requires special attention. In particular, the creation of conditions for a significant increase in the volume of freight and passenger traffic, the creation of a transport and logistics hub. 
Freight turnover and volume of GRP per person in the Nikolaev region have a linear approximation, which indicates a direct influence and interdependence, which is characterized by growth at a constant rate; in the Odessa and Kherson regions is in a polynomial relationship of 4 degrees and 2 degrees, respectively, which indicates an interconnected alternating increase and decrease in the values of indicators, i.e. unstable influence.

The strategic priority for the development of the transport system of the Nikolaev region should be the optimization of the use of infrastructure and transit opportunities to improve local accessibility. This requires stimulating the construction and reconstruction of highways, using the potential of special economic zones and priority development areas, stimulating the development of intermodal transport. To optimize the procedure for moving goods to the place of using electrification of railway sections, which allows to reduce the time of transportation and open a direct exit of railway transport to ports of Nikolaevskaya, river and sea freight flows dock, there is a redistribution of these freight flows, they are further transported by all types of transport - sea, river, rail and road. This gives a powerful impetus to the development of transport corridors in the region. A significant component of the economy of the Nikolaev region is the activity of handling cargo arriving at sea and river berths. Another important issue for the region is the development and further development of the airport "Nikolaev", which belongs to one of the largest in the south of Ukraine, but whose potential almost never used. Despite the fact that the Odessa region is distinguished by a favorable transport and geographical position, which leads to the leading role of transport in its development, among the main priorities is the development and development of a national logistics hub on the territory of the Odessa region, an increase in freight and passenger traffic, the interaction of all types of transport as a basis creating a multimodal transport hub, developing tourism, improving the investment climate and increasing the volume of attracting investments, which are a condition for the development of not only the transport industry, but also the national security and competitiveness of the country. Considering that the Kherson region stands out among the regions of Southern Ukraine with a low level of urbanization, the structure of the regional economy and in its typology is close to the Sumy, Kirovograd, Chernihiv and Vinnitsa regions, due to its favorable location and the presence of important main railways, the region has a significant transit potential and needs to attract investments for the development of the settlement system and increase the anthropogenic load of the territory without damage to the environment.

\section{Conclusions, proposals, recommendations}

1) The study of the indicators of freight turnover and GRP per capita by regions of Ukraine showed that these indicators are less than $80 \%$ of the national average in 10 regions of Ukraine (that is, almost half). Among them - Chernivtsi and Transcarpathian regions have an indicator of less than $55 \%$ of the average, and Luhansk - only $21.49 \%$. At the same time, the ratio between the minimum and maximum GRP per capita, excluding the indicators of the city of Kiev, increased almost 2 times and is 7.59 times. This indicates that the transport system of Ukraine has a low level of development of transport and logistics technologies and objects of multimodal transportation, which reduces its competitiveness and limits the exit of Ukrainian products to the world transport market.

2) The authors investigated 24 regions of Ukraine, taking into account the time, geographic, statistical, economic and infrastructural criteria. Models of interdependence of freight turnover and GRP per person in the regions of Ukraine have been built. Of the obtained models, 12 are reliable and statistically significant with a 95 \% reliability level. These include Vinnytsia, Volynsky, Zaporozhye, Kiev, Lvov, Odessa, Poltava, Sumy, Kharkov, Khmelnitsky, Cherkassy and Chernivtsi regions. 
3) The comparative analysis of the transport provision of the regions of Ukraine with the regressions and trends of freight turnover and GRP per capita showed the potential possibilities of using and developing the infrastructure of the regions of Ukraine. The research results can be used in the implementation of interregional projects by providing access to transport connections for all regions within the framework of the National Transport Strategy 2030, to form territorial integrity. The results can be used in the formation and implementation of draft resolutions of the Cabinet of Ministers of Ukraine "On the approval of the State strategy for regional development for the period up to 2027" in the field of transport based on multimodality and intermodality. This will contribute to the achievement of the priority goal of the state authorities - ensuring interregional integration as the basis for the development of the transport space of Ukraine and compliance with the policy of the European Union.

4) As a result of the research carried out, interregional integration was proposed in the following regions: Zaporozhye, Nikolaev, Lvov, Odessa, Rivne. On the basis of the "Zaporozhye International Airport" it is possible to create a large multimodal logistics center for the transportation and storage of goods with the construction of a cargo terminal. The geographical location of the Nikolaev transport hub on the way of transporting goods from west to east determines its role as an intermodal center for economically profitable schemes for the movement of freight flows. The favorable location of the Lviv region and the presence of international transport corridors, important main railways play a leading role in increasing freight traffic and developing a transport (logistics) hub in the region. The interaction of all types of transport on the territory of Odessa is a prerequisite for the development and development of the national logistics hub of the region and the basis for creating a multimodal transport hub in the region. The Rovny region is favorable for the creation of a transport and logistics hub for multimodal transportation due to the creation of conditions for a significant increase in the volume of freight traffic.

5) Thus, it is substantiated that the state regional policy in the transport sector should be aimed at introducing effective tools to stimulate interregional integration. Integration of regional economic, information, educational spaces into a single transport space is of great importance. This will make it possible to overcome interregional alienation and introduce effective instruments of state support for interregional integration, the implementation of interregional programs and projects.

\section{Acknowledgements}

Participation in the conference was funded by European Regional Development Fund (ERDF), Measure 1.1.1.5 "Support to international cooperation projects in research and innovation of RTU". Project No. 1.1.1.5/18/I/008.

\section{Bibliography}

1. Braginskiy, V.V. (2011). The Development of Transport and Logistics System as a Form of Realization of Transit Potential of Ukraine. Public Administration: Theory and Practice, Volume 2. Retrieved: http://academy.gov.ua/ej/ej14/txts/Braginskiy.pdf Access: 15.12.2020.

2. Chernyshev, V., Okara, D., Kovalova, I. (2019). Foreign Economic Activity of Regions in Ukraine. Efektyvna Ekonomika, Volume 6. DOI: https://doi.org/10.32702/2307-2105-2019.6.53

3. Demianchuk, M., Bezpartochnyi, M., Filipishyna, L., \& Zivitere, M. (2021). The Model of Achieving a Balanced Balance Between Economic Efficiency and Ecological-Social Responsibility of Digitalized Enterprise. Journal of Optimization in Industrial Engineering. Volume 14, Issue 1, pp. 63-70. DOI: https://doi.org/10.22094/JOIE.2020.677817.

4. aDemianchuk, M., Maslii, N., \& Skribans, V. (2019). GRP Econometric Models for Regions of Ukraine. ICEME 2019, 15-17, July, Beijing, China, pp. 6-11. DOI: https://doi.org/10.1145/3345035.3345056.

5. bDemianchuk, M., Maslii, N., \& Skribans, V. (2019). Bifurcation Points Analysis Application in Economic Studies. ICIBE 2019, 27-29, September, Hong Kong, China, pp. 359-364. DOI: https://doi.org/10.1145/3364335.3364405. 
6. Gadelshina, L.A., Vakhitova, T.M. (2015). The Place and Role of Transport Infrastructure in the Interregional Integration of the Russian Federation Regions. Procedia Economics and Finance, Volume 24, pp. 246-250, DOI: https://doi.org/10.1016/S2212-5671(15)00655-3.

7. Hansen, W., Johansen, B.G. (2017). Regional Repercussions of New Transport Infrastructure Investments: an SCGE Model Analysis of Wider Economic Impacts. Research in Transportation Economics, Volume 63, pp. 38-49, DOI: https://doi.org/10.1016/j.retrec.2017.07.004.

8. Hudyma, R.R. (2013). Assessment of Baseline Transport Security Border Region. Socio-Economic Problems of the Modern Period of Ukraine, Volume 4 (102). Retrieved: http://ird.gov.ua/sep/sep20134(102)/sep20134(102)_075_HudymaRR.pdf Access: 15.12.2020.

9. Ilchenko, S. V., Mezina, L. V., Mashkantseva, S. O. (2019). Parfmetric Features and Criteria of the Development of the Market for Linear Transportation. Financial and Credit Activity Problems of Theory and Practice, Volume 4, № 31, pp. 184-195. DOI: https://doi.org/10.18371/fcaptp.v4i31.190832.

10. Ivanov, S.V., Lyashenko, V.I., Shamileva, L.L., Trushkina, N.V. (2019). Development Trends of the Transport and Logistics System of the Prydniprovsky Economic Region. Visnyk ekonomichnoi nauky Ukrainy, Volume 2 (37), pp. 143-150. DOI: https://doi.org/10.37405/1729-7206.2019.2(37).143-150

11. Karpenko, O.O., Babyna, O.Y. (2013). Intensification of Development of Mixed Transportation of Freight in Ukraine through Formation of the Network of Transportation and Logistic Centres and Transportation and Logistic Clusters. Business Inform, Volume 11, pp. 180-185. Retrieved: https://www.businessinform.net/export_pdf/business-inform-2013-11_0-pages-180_185.pdf Access: 15.12.2020.

12. Khrustalyova, V.V. (2013). Transport Industry of Ukraine and Analysis of Ways to Increase Competitiveness. Economics. Management. Innovations, Volume 1. Retrieved: http://nbuv.gov.ua/UJRN/eui_2013_1_64 Access: 15.12.2020.

13. Maslii, N. (2020). Implementation of Regulatory and Legal Support for Multimodal Transportation at the National and International Levels. Black Sea Economic Studies, Volume 51, pp. 52-55. DOI: https://doi.org/10.32843/bses.51-8.

14. Maslii, N., Kotenko, S., \& Zhadanova, Y. (2020). Efficiency of Managing Combined Transportation on the Basis of Forming a Logistic Center and Applying Innovative-Information Technologies. Economic Innovations, Volume 22, Issue 1(75), pp. 61-70. DOI: https://doi.org/10.31520/ei.2020.22.2(75).61-70.

15. Meersman, H., Nazemzadeh, M. (2017). The Contribution of Transport Infrastructure to Economic Activity: The Case of Belgium. Case Studies on Transport Policy, Volume 5, Issue 2, pp. 316-324, DOI: https://doi.org/10.1016/j.cstp.2017.03.009.

16. Mohino, I., Urena, J.M., Solís, E. (2016). Transport Infrastructure and Territorial Cohesion in Rural MetroAdjacent Regions: a Multimodal Accessibility Approach. The Case of Castilla-La Mancha in the Context of Madrid (Spain). Journal of Transport Geography, Volume 57, pp. 115-133, DOI: https://doi.org/10.1016/j.jtrangeo.2016.10.001.

17. Pashchenko, Yu.E. (2003). Development and Placement of the Transport and Road Complex of Ukraine: Monograph / ed. S.I. Doroguntsov. Kiev: Naukovyy svit, p. 467.

18. Pokharel, R., Bertolini, L., Brömmelstroet, M., Acharya, S.R. (2021). Spatio-Temporal Evolution of Cities and Regional Economic Development in Nepal: Does Transport Infrastructure Matter?, Journal of Transport Geography, Volume 90, 102904, DOI: https://doi.org/10.1016/j.jtrangeo.2020.102904.

19. Shyriaieva, S.V. (2012). Logistics Multimodal Transport. The National Transport University Bulletin. Volume 26(2), pp. 358-362. Retrieved: http://publications.ntu.edu.ua/visnyk/26_2_2013/358-362.pdf Access: 15.12.2020.

20. Soyres, F., Mulabdic, A., Ruta, M. (2020). Common Transport Infrastructure: a Quantitative Model and Estimates From the Belt and Road Initiative. Journal of Development Economics, Volume 143, 102415. DOI: https://doi.org/10.1016/j.jdeveco.2019.102415.

21. State Statistics Service of Ukraine (n.d.). Statistical Information. Retrieved: http://www.ukrstat.gov.ua/operativ/oper_new.html Access: 15.12.2020.

22. Stetsyuk, V.V., Kostyaeva, K.V. (2017). Methodical Approaches to Assessing the Effective Involvement of Railway Transport in the Region's Logistic Systems. Logistics and Supply Chain Management, Volume 5 (82). Retrieved: http://www.Iscm.ru/index.php/ru/po-godam/item/1622 Access: 15.12.2020.

23. Yu, N., Jong, M., Storm, S., Mi, J. (2013). Spatial Spillover Effects of Transport Infrastructure: Evidence from Chinese Regions. Journal of Transport Geography, Volume 28, pp. 56-66, DOI: https://doi.org/10.1016/j.jtrangeo.2012.10.009.

24. Zastavny, F.D. (2010). Economic Regions of Ukraine. Lviv: Apriori. p. 207. 